\title{
TEXTILE AS A SUSTAINABLE INSULATING MATERIAL FOR BUILDINGS
}

\author{
Sonja Jordeva ${ }^{1 *}$, Sashka Golomeova Longurova, \\ Marija Kertakova', Kiro Mojsov' ${ }^{1}$, Jordan Efremov ${ }^{2}$
}

\author{
1 University "Goce Delchev", Shtip, Faculty of Technology \\ Miro Baraga bb., Probištip, Republic of North Macedonia \\ 2 University "Goce Delchev", Shtip, Art Academy, \\ Krste Misirkov 10-A, Štip, Republic of North Macedonia \\ *e-mail: sonja.jordeva@ugd.edu.mk
}

\author{
Pregledni rad \\ UDC: 677.024 .074 \\ doi:10.5937/tekstind1902020J
}

\begin{abstract}
The introduction of the concept of "sustainability" in the construction industry has led to the production of alternative insulation products made of textiles from virgin or recycled materials, besides the conventional ones. Some of them are already present in the European market, while others are still being researched. There is no ideal insulation material, so it is useful to evaluate conventional and alternative insulating materials. The assessment of insulation materials is an issue which needs to be analyzed from different aspects: the physical properties of the material, their effect on people and the environment, installation difficulty and price. In this paper, conventional and alternative insulation materials from textiles are examined in terms of sustainability criteria. Insulation materials from recycled textiles are considered sustainable materials due to the possibility of recycling, reuse and low value of embodied energy. However, as a result of insufficient consumer awareness, insulating materials from textiles are not represented in the markets as much as they deserve to be.
\end{abstract}

Key words: insulation, recycled textiles, evaluation.

\section{TEKSTIL KAO ODRŽIVI IZOLACIONI MATERIJALZA ZGRADE}

Apstrakt: Uvođenje koncepta "održivosti" u građevinskom sektoru dovelo je do proizvodnje alternativnih izolacionih proizvoda od tekstila, osim konvencionalnih. Neki od njih su već prisutni na evropskom tržištu, dok su drugi još uvijek u fazi istraživanja. Ne postoji idealan izolacioni materijal, zato je korisno napraviti evaluaciju konvencionalnih i alternativnih izolacionih materijala. Procena izolacionih materijala je pitanje koje treba analizirati iz različitih aspekata: fizičkih svojstava materijala, njihovog uticaja na ljude i okolinu, težine instalacije i cene. U ovom radu su ispitivani konvencionalni i alternativni izolacioni materijali od tekstila u kontekstu kriterijuma održivosti. Izolacioni materijali od recikliranog tekstila smatraju se održivim zbog mogućnosti ponovne upotrebe, recikliranja i niske vrednosti skrivene energije. Međutim, kao rezultat nedovoljne svesti potrošača, izolacioni materijali od tekstila nisu zastupljeni na tržištima u onolikoj meri koliko zaslužuju.

Ključne riječi: izolacija, recikliran tekstil, evaluacija.

\section{INTRODUCTION}

There are two dominant groups of conventional insulation materials for buildings in the European market: inorganic fibrous-stone and glass wool (60\%), and organic foamy materials - expanded and extruded polystyrene (27\%). The remaining $13 \%$ consist of other materials, [1]. The most important physical properties of every insulation material are the coefficient of thermal conductivity $-\lambda(\mathrm{W} / \mathrm{mK})$, resistance to vapour diffusion, the sound absorption degree and density $\left(\mathrm{kg} / \mathrm{m}^{3}\right)$. Most of the typical thermal-insulation materials have a coefficient of thermal conductivity between $\lambda=0.030-0.045(\mathrm{~W} / \mathrm{mK})[1,2]$. 
There is no ideal insulation material. In addition to the advantages, each material has some disadvantages. It is therefore useful to make a comparative analysis of insulating materials. There are many differences in the physical properties of inorganic and organic conventional insulation materials due to their different nature and chemical composition. Both materials are characterized by their very low thermal conductivity. Stone wool outperforms extruded polystyrene in a few important characteristics. It has a wider temperature range of use, high sound-proofing qualities, which have become a vital characteristic of building structures over the last years, and high fire resistance, which is important in implementing strict fire proctection standards. Furthermore, stone wool is a more environmental friendly material than extruded polystyrene since it presents lower embodied energy and $\mathrm{CO}$ and $\mathrm{CO}_{2}$ emissions during the production process. Table 1 shows a comparison of stone wool, glass wool and polystyrene, [3].
The ecological trend, as well as the increasing demand for insulation materials, has led to the development of new technologies and a range of new materials such as transparent thermal insulation, vacuum thermal insulation, gas insulation materials, nano insulation materials and dynamic insulation materials. As a good alternative, insulation materials from textiles and recycled textiles are considered as having no shortcomings in terms of their harmful effects on human health and the environment, and on the other hand, they are much cheaper than vacuum, gas and nano-insulating materials, [5]. Insulation materials from textiles and recycled textiles are a good alternative as they are considered to have no shortcomings in terms of harmful effects on human health and the environment. In addition, they are much cheaper than vacuum, gas and nano-insulating materials.

Textile is traditionally used in buildings for aesthetic needs, but it also shows a lot of functional performances. It can be used for thermal and sound insulation due

Table 1: Comparative analysis of conventional insulating materials, [3]

\begin{tabular}{|c|c|c|}
\hline Material & Advantages & Disadvantages \\
\hline Stone wool (rolls) & $\begin{array}{l}\text { Non-flammable material } \\
\text { Good steam permeability } \\
\text { Excellent sound insulator } \\
\text { Mechanical stability }\end{array}$ & $\begin{array}{l}\text { High price } \\
\text { Poor pressure resistance } \\
\text { Poor waterproofing }\end{array}$ \\
\hline Stone wool (panels) & $\begin{array}{l}\text { Non-flammable material } \\
\text { Good steam permeability } \\
\text { Excellent sound insulator } \\
\text { Mechanical stability }\end{array}$ & $\begin{array}{l}\text { High price } \\
\text { Poor pressure resistance } \\
\text { Poor waterproofing } \\
\text { Requires installation }\end{array}$ \\
\hline Glass wool & $\begin{array}{l}\text { Non-flammable material } \\
\text { Good steam permeability } \\
\text { Excellent sound insulator } \\
\text { Resistant to microorganisms }\end{array}$ & $\begin{array}{l}\text { High price } \\
\text { Poor pressure resistance } \\
\text { Poor waterproofing } \\
\text { Requires installation }\end{array}$ \\
\hline Polystyrene hard foam & $\begin{array}{l}\text { Low price } \\
\text { Lightweight material } \\
\text { Good resistance to pressure }\end{array}$ & $\begin{array}{l}\text { Flammable material } \\
\text { Poor permeability of steam } \\
\text { Poor sound insulator }\end{array}$ \\
\hline
\end{tabular}

The production of ecological products with reduced harmful effects on the environment has become a priority in the countries of the European Union. Ecological labeling of the products in the EU started with the application of EEC num. 880/92 EU Council in 1992, aiming to motivate the business sector to develop products that would fit in the scheme of ecological products Eco-labels are awarded according to unique ecological criteria that show that products do not contain ozone-depleting chlorofluorocarbons, can be recycled and that they are energy efficient, [4]. to its relatively porous structure, especially non-woven textiles.There is a lot of research conducted on the insulation characteristics of non-woven textiles, fabrics and knitwear, however much less research has been done for the use of textile waste as a insulation material. The main goal of the paper is to present state of the art in alternative thermal and acoustic insulating materials made of virgin and/or recycled textile materials and their evaluation in context of the sustainability. 


\section{STATE OF THE ART IN ALTERNATIVE INSULATING MATERIALS FROM VIRGIN AND/OR RECYCLED TEXTILE MATERIALS}

Because of its natural properties, especially its thermal efficiency, sheep wool is an excellent insulation material. In the research project of the University of Brno and the Technological University of Vienna [6], the properties of environmentally friendly thermal insulation materials made of sheep wool have been examined. The results show that insulation from the sheep' wool has characteristics similar to those of mineral wool, and in relation to the ecological components and the impact on human health, it is absolutely dominant. The benefits of sheep wool include the following: clean and easy to renew natural material source, comfortable and easy to handle without potential risk to human health (irritation of the skin, mucous membranes etc.), easy to recycle, eco-friendly, relaxation of the material, there is neither change in volume nor loss of elasticity, highly hygroscopic (up to $35 \%$ ). Moisture absorption is a very important feature for the functionality of each insulating material. Due to the high capacity of the wool insulation to absorb moisture, it prevents condensation and creates a pleasant atmosphere in indoor spaces. In addition, the same research shows that the wool insulation is an excellent acoustic insulator. natural textile fibers. Textile waste has already found a commercial use as an insulation material. However, only waste suitable for mechanical recycling (easy to open down to fibers) has been used.

"Inno-Therm", a company from Great Britain, produces insulation from recycled industrial cotton material-denim (from rough cotton yarn, $\mathrm{Tt}=60-100 \mathrm{Tex}$ and mass of $200-400 \mathrm{~g} / \mathrm{m}^{2}$ ) which is a form of safe and eco-friendly insulation.The material is processed with fire-retardant finish. The products are in the form of a roll (Figure 2a) or panels. The coefficient of thermal conductivity is $\lambda=0.037-0.038 \mathrm{~W} / \mathrm{mK}$ and the material has a $10 \%$ better sound insulation than the prescribed ASTM/USA standards. According to the manufacturer of this insulation, some of the more important reasons for its use are: it is a product under licensed regenerated insulation, it helps to reduce the amount of textile waste and represents an ideal eco-product, it requires much less energy for production than conventional insulation, it meets the standards for fire resistance, offers antibacterial and corrosion protection, and it is a biodegradable material. It also reduces the size of the structural frame in the inner walls, it can be used for floor insulation and as well as soundproofing, it does not contain irritating chemicals, it is easily manipulated (no need of protective equipment for installation) and has a pleasant touch, [7].
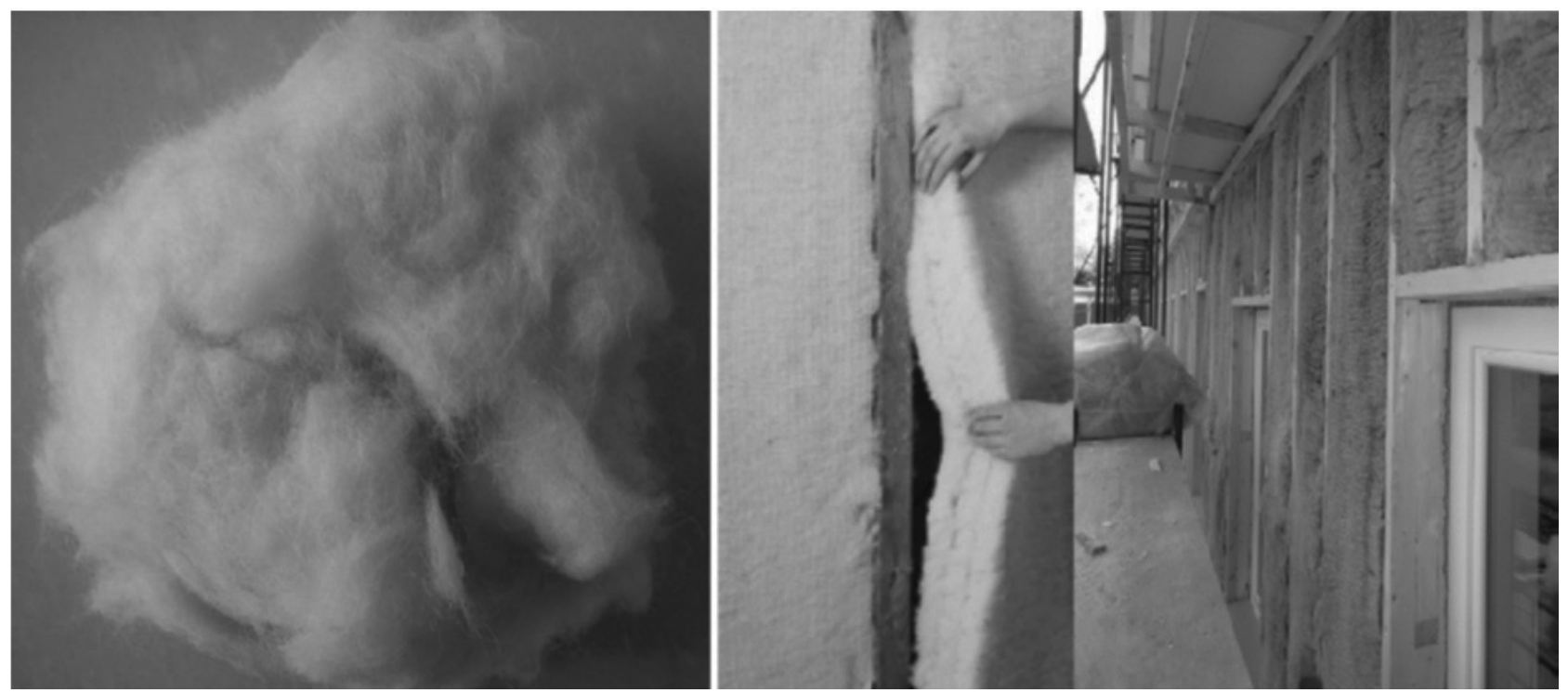

Figure 1: Application of wool for insulation of buildings, [6]

Despite all the well-known advantages of wool insulation for buildings, there are almost no such materials in practice because of their high price. Not only wool insulation, but any insulation from natural textile fibers, for example, cotton, is very expensive. A better alternative is to use recycled textile waste from
"Le Relais", the French recycling company, which collects 45000 tons of used textiles annually, developed a thermal insulation product called Mettise (Figure $2 b)$. The product contains at least $85 \%$ recycled fibers and consists of cotton (70\%), wool / acrylic (15\%) and polyester (15\%) which is added as a binder. The ma- 
terial is further processed against fungi and insects, and the products are in the form of rolls and panels of various thicknesses and densities. The roll density is, and the thickness while the density of the panels is, and the thickness The coefficient of thermal conductivity of these materials is $\mathrm{W} / \mathrm{mK}$. The value of thermal insulation of Mettise is comparable with the thermal insulation of glass and stone wool. It is used for insulation of ceilings, roofs and walls. The company also produces specialized acoustic insulation materials with a thickness of $h=20 \mathrm{~mm}$ for rolls or $\mathrm{h}=45 \mathrm{~mm}$ for panels, and the density is in both cases $\rho=45 \mathrm{~kg} /$ $\mathrm{m}^{3}[7,8]$. In addition to thermal and acoustic insulation, Mettise products have outstanding mechanical properties, [8].
The Scottish research and design studio "Kraft Architecture" has developed an insulation product "Thermobond" [9] which is designed for insulaton of roofs, exterior walls and floors. Thermobond is made from $100 \%$ recycled textile that comes from the Scottish wool industry. The wool is combined with $8 \%$ polyester as a binder. The product is further processed against burning and has a thermal conductivity of $\lambda$ $=0.034 \mathrm{~W} / \mathrm{mK}$.

A new insulation material from textile waste has been made in Portugal [10]. The textile subwaste (Figure 3 ) resulting from the mattress industry is the thermal insulation material that has been designed and examined. The samples are mainly acrylic and their particles have a diameter between $8 \mu \mathrm{m}$ and $15 \mu \mathrm{m}$.

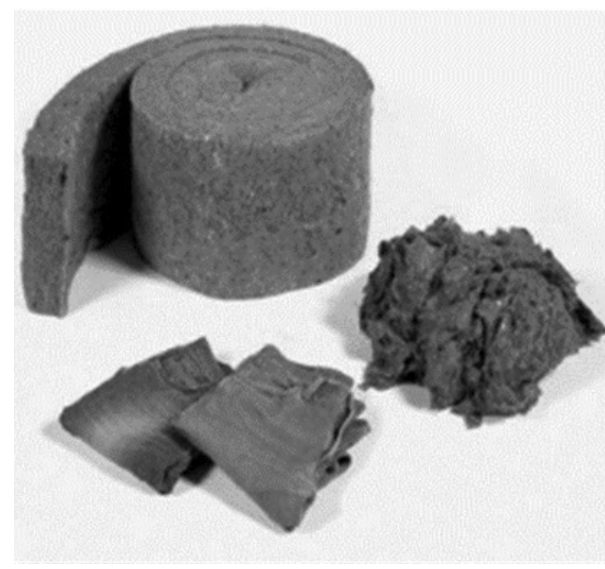

a) Inno-Therm roll

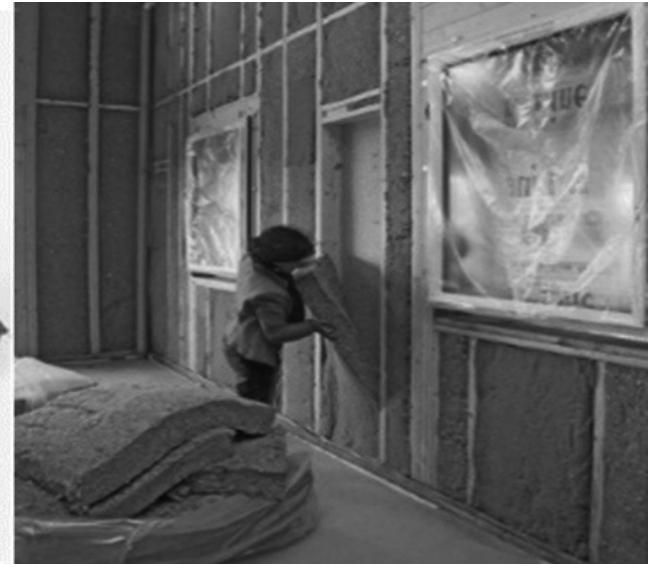

b) Mettise panel

Figure 2: Insulation from recycled cotton material, [7,8]

Appart from the products mentioned above that have already found a commercial application as insulation materials, there are numerous research projects to develop alternative insulating materials that come from the recycling process. Following is a short overview of the latest research in this area.
The results of the research show the excellent potential of this material for the use as insulation in double inner walls.

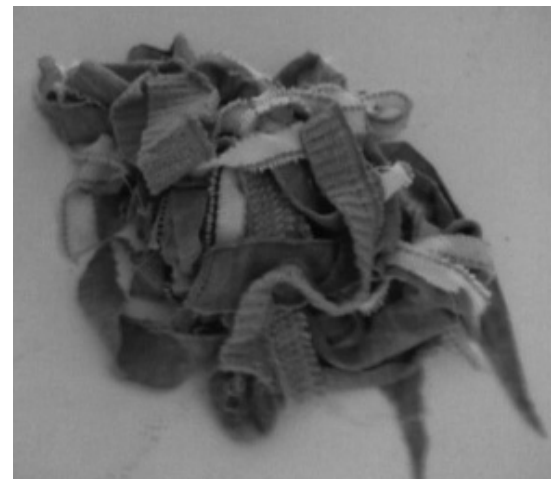

a) Tissue waste

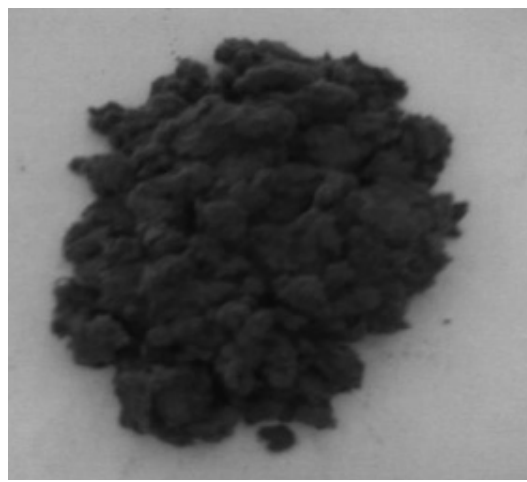

b)Tissue subwaste

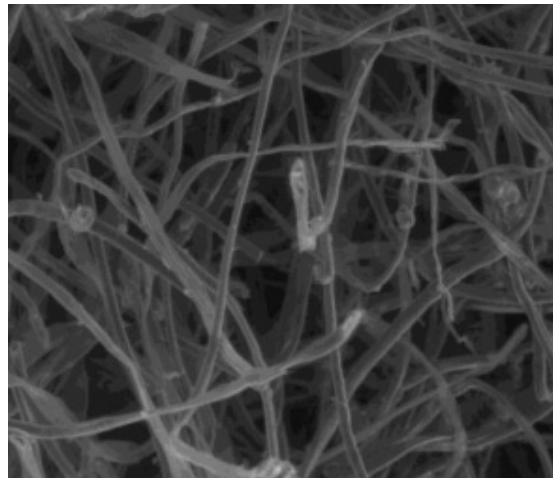

c) Microstructure of the tissue subwaste

Figure 3: Textile waste and the microstructure of the textile subwaste, [10] 
A new insulation material of polyester waste from tailoring materials for underwear has been made in the form of panels with dimensions of $200 \times 200 \times 5 \mathrm{~mm}$ (length $\times$ width $\times$ depth) of different densities. It was manufactured in a thermoforming hot plate at a temperature of 190 and by applying constant pressure for $15 \mathrm{~min}$. The thermal insulation properties were evaluated by the guarded comparative longitudinal heat flow technique. The thermal conductivity of the panels was obtained in a range between 0.053 and $0.041 \mathrm{~W} /$ $\mathrm{mK}$, depending on the density. The obtained values were similar to other commercial insulation materials [11].

Narang's [12] research was focused on examining the sound absorption coefficient of polyester materials with regard to mass density and sample thickness values. The tests were carried out on internal walls, filled with materials made of polyester non-woven textile (felt) with different surface masses. A coefficient of transmission loss (STC), which defines a transmission loss class, was determined. The results show that the addition of cut polyester pieces increases the class of sound transmission, i.e. sound insulation. STC enhancement occurs at all frequencies in the interval of $100-500 \mathrm{~Hz}$. To achieve the maximum STC value, the optimal surface mass of the polyester material is 1000 or more. Whether the material is virgin (original) or recycled, the efficiency of sound absorption materials is related to the porous structure and thickness of the elements.

Table 2 shows the results [13] of the acoustic characteristics of conventional and polyester insulating materials. The polyester material with a thickness of $h$ $=45 \mathrm{~mm}$ and density has a better sound absorption coefficient, even compared to conventional materials such as stone and glass wool.
A very interesting example is the production of thermal insulation materials from recycled PET, that is, from plastic bottles [14]. The thermal insulation material is in the form of a panel. The technical performances of the new material are: density $\rho=35.5$ $\mathrm{kg} / \mathrm{m}^{3}$, coefficient of thermal conductivity $=0.0355$ $\mathrm{W} / \mathrm{mK}$ and thermal resistance $\mathrm{R}=1 \mathrm{~m}^{2} \mathrm{~K} / \mathrm{W}$. The energy saved when applying the thermal insulation in a building in Rome is estimated at $87 \mathrm{MJ} / \mathrm{m}^{2}$ per unit area annually. All the energy used during the production of a thermal insulation panel is recovered in about 2 years. The production consists of three phases: recycling, spinning and formation of non-woven products. The durability of these insulating panels is 60 years, roughly the lifetime of buildings.

Trajković et al. [15] and Jordeva et al. [16,17,18] produced an insulating material encasing different fabric mixtures in a $100 \%$ polypropylene non-woven structure. The mix used for this research is $100 \%$ polyester (blends $A$ and $C$ differing in the size of the waste), polyester/cotton/lycra (blend B: 70/25/5) and polyester/lycra (blend D: 95/5). The obtained $\lambda$ values are similar to standard insulation materials $(\lambda=0.030$ $0.045 \mathrm{~W} / \mathrm{mK})$, as well as commercial insulation structures from textile fibers $(\lambda=0.039-0.041 \mathrm{~W} / \mathrm{mK})$. The test results also showed that the structure containing smaller pieces of cutting fabric had the highest thermal insulation. The presence of lycra in the samples decreased the thermal insulation of the structure.

In addition, Jordeva et al. [19] examined the sound insulation properties of the proposed insulation structure composed of polyester apparel cutting waste. The obtained insulation structures exhibit sound absorption properties typical of fibrous materials. The achieved sound absorption, with a NRC- noise reduction coefficient ranging from $54.71 \%$ to $74.77 \%$ is comparable to commercially used insulators, such

Table 2: Thickness - $h$, density - $\rho$ and sound absorption coefficient - $a$ of conventional and polyester insulating materials, [13]

\begin{tabular}{|c|c|c|c|c|c|c|c|}
\hline \multirow[b]{2}{*}{ Material } & \multirow{2}{*}{$\stackrel{\stackrel{h}{h}}{(\mathrm{~mm})}$} & \multirow{2}{*}{$\begin{array}{c}\rho \\
\left(\mathrm{kg} / \mathrm{m}^{3}\right)\end{array}$} & \multicolumn{5}{|c|}{$\alpha$} \\
\hline & & & $\begin{array}{l}250 \\
(\mathrm{~Hz})\end{array}$ & $\begin{array}{l}500 \\
(\mathrm{~Hz})\end{array}$ & $\begin{array}{l}1000 \\
(\mathrm{~Hz})\end{array}$ & $\begin{array}{l}2000 \\
(\mathrm{~Hz})\end{array}$ & $\begin{array}{c}250-2000 \\
(\mathrm{~Hz})\end{array}$ \\
\hline $\begin{array}{l}\text { Glass } \\
\text { wool }\end{array}$ & 50 & 50 & 0.45 & 0.65 & 0.75 & 0.80 & 0.663 \\
\hline $\begin{array}{l}\text { Stone } \\
\text { wool }\end{array}$ & 50 & 80 & 0.29 & 0.52 & 0.83 & 0.91 & 0.638 \\
\hline Polyester & 45 & 20 & 0.56 & 0.85 & 0.98 & 0.95 & 0.835 \\
\hline
\end{tabular}


as glass wool (NRC $=66.3 \%$ for thickness of $50 \mathrm{~mm}$ and density of $\left.50 \mathrm{~kg} / \mathrm{m}^{3}\right)$, stone wool (NRC $=63.8 \%$ for thickness of $50 \mathrm{~mm}$ and density of $\left.80 \mathrm{~kg} / \mathrm{m}^{3}\right)$, polystyrene $(\mathrm{NRC}=51.8 \%$ for thickness of $50 \mathrm{~mm}$ and density of $\left.28 \mathrm{~kg} / \mathrm{m}^{3}\right)$.

\section{EVALUATION OF INSULATION MATERIALS IN THE CONTEXT OF SUSTAINABILITY}

The evaluation of insulation materials is a multicriteria problem, which has to be carried out with respect to their: physical properties (thermal insulation,density, mechanical strength, sound absorption, resistance to moisture and fire), applicability in specific building elements and their cost, environmental impact and their impact on human health. Physical characteristics of the insulation materials are determined based on measurements, and the results are compared to standard values, so it is relatively easy to evaluate from this aspect. It's also not a problem to evaluate the difficulty of installation, as well as the price of the materials, [1]. There is another group of less clearly stated, and even less commonly accepted criteria that deals with the environmental impact of insulating materials. This group includes properties like the primary embodied energy, the gas emissions for the production of the material, the use of additives against biological impacts, the classification of their treatment as waste, etc., their reusability and recyclability and the environmental impact of the material, based on the Life Cycle Analysis approach according to ISO 14025-00, [20].

Finally, there is the group of properties dealing with public health, during the production, the use and at the final stage of disposal of the materials. This group includes properties like dust and fibres emissions, biopersistence, toxicity in case of fire, etc. [21].

LCA is often used to assess the sustainability of a product and its environmental footprint. The relevant factors in the life-cycle assessment of the product according to U.S. EPA (SAIC, 2006) are the following [22]: ozone depletion, global warming (GWP), smog formation, acidification, eutrophication, carcinogenic diseases in humans, non-cancerous diseases in humans, ecotoxicity, reduction of fossil fuel reserves, use of water. Global Warming Potential (GWP is the relative measure of the amount of heat generated by the so-called greenhouse effect in the atmosphere. GWP is calculated for a specific time interval, usually 20, 100 or 500 years. GWP is expressed through a carbon diox- ide factor (whose GWP is standardized at 1). For example, GWP of methane for 20 years is 72 , which means that if the same mass of methane and carbon dioxide is introduced into the atmosphere, the methane will capture 72 times more heat than carbon dioxide over the next 20 years [23].

The Life Cycle Assessment of an insulation material also includes factors like useful life, availability of raw materials, resource consumption during production, and health effects during production. One of the most important aspects though, is the structure's energy consumption throughout its useful life, since (when all is said and done) insulation materials are intended to save energy, [24].

The LCA study developed by DEFRA [25] shows the advantages of building insulation materials from natural fibers compared to others, mostly in the area of GWP, due to the reduction of carbon dioxide in the atmosphere. Another big area where they have the advantage is climate change. A specific element of the study is an evaluation of the potential for optimisation of the environmental profile of natural fibre insulation materials. The materials investigated in this study were Isonat, a hemp/recycled cotton based material and Thermafleece which is produced mainly from waste sheep wool.The study was done at the initial stage of the development of these products with the aim of using the results to improve the quality of the product. As a guide data from the previous research, i.e. analysis of the life cycle of stone wool produced by KNAUF was used. The basic unit selected in the research is the insulation of $1 \mathrm{~m}^{2}$ of surface. The impact of Isonate - material was slightly higher than Thermafleece - material in several impact categories. The results of the study show that density should be reduced, especially in Isonat materials which offer excellent acoustic insulation. The main conclusion of this study is that the analyzed insulation materials have a positive contribution against global warming by reducing the amount of and it is recommended to increase the production and use of these materials instead of conventional insulating materials. It must be considered that there is no material that will meet all the criteria in an evaluation of insulation materials.

Papadopoulos and Idil $[1,2,26]$ have done a lot of research on insulating materials in the context of the sustainability criteria. Table 3 is made based on their investigations. 
Table 3: Evaluation of insulation materials in the context of sustainability criteria $[1,2,26]$

\begin{tabular}{|c|c|c|c|c|c|c|c|c|c|}
\hline \multirow{2}{*}{ } & \multicolumn{2}{|c|}{ Inorganic/mineral } & \multicolumn{3}{|c|}{ Organic/Synthetic } & \multicolumn{3}{|c|}{ Organic } & \multirow{2}{*}{ 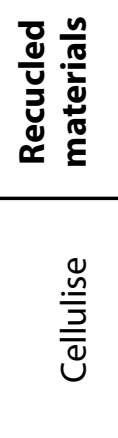 } \\
\hline & $\begin{array}{l}\bar{O} \\
0 \\
3 \\
0 \\
\frac{1}{0} \\
\stackrel{\sim}{n}\end{array}$ & $\begin{array}{l}\bar{O} \\
0 \\
3 \\
\tilde{n} \\
\tilde{\sigma}\end{array}$ & $\begin{array}{l}\frac{0}{c} \\
\frac{0}{0} \\
\frac{1}{1} \\
\frac{0}{2} \\
\frac{\lambda}{0} \\
0\end{array}$ & 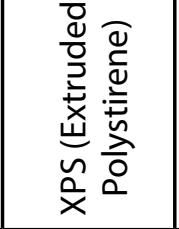 & 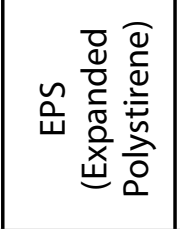 & 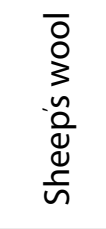 & 䇉 & 호 & \\
\hline $\begin{array}{l}\text { Embodied } \\
\text { energy (MJ/ } \\
\text { kg) }\end{array}$ & 20 & 35 & 135 & 133 & 125 & 29 & 14.5 & 30 & 19 \\
\hline $\begin{array}{l}\lambda \\
(\mathrm{W} / \mathrm{mK})\end{array}$ & $\begin{array}{l}0.035- \\
0.050\end{array}$ & $\begin{array}{l}0.035- \\
0.050\end{array}$ & $\begin{array}{c}0.030- \\
0.035\end{array}$ & $\begin{array}{l}0.028- \\
0.032\end{array}$ & 0.04 & 0.04 & 0.052 & $\begin{array}{l}0.045- \\
0.055\end{array}$ & $\begin{array}{l}0.035- \\
0.045\end{array}$ \\
\hline $\begin{array}{l}\text { Amount of } \\
\text { reserves } \\
\text { (years) }\end{array}$ & 41 & 35 & - & - & - & 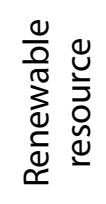 & 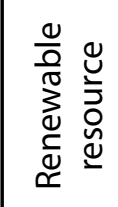 & 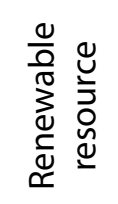 & 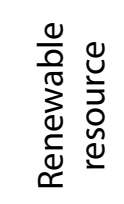 \\
\hline $\begin{array}{l}\text { Water use in } \\
\text { production } \\
(\mathrm{l} / \mathrm{kg})\end{array}$ & 1360 & 1360 & - & - & - & - & - & 25 & 10 \\
\hline $\begin{array}{l}\text { Life cycle } \\
\text { (years) }\end{array}$ & $30-50$ & $30-50$ & $30-50$ & 50 & 50 & - & - & $50-80$ & - \\
\hline $\begin{array}{l}\text { Reusability } \\
\text { and } \\
\text { Recyclability }\end{array}$ & 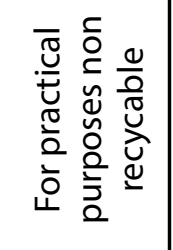 & 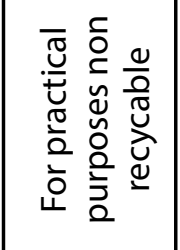 & 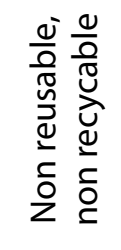 & 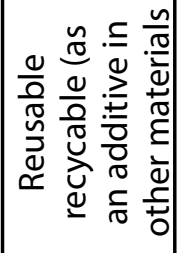 & 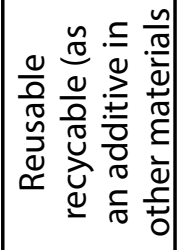 & 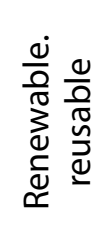 & 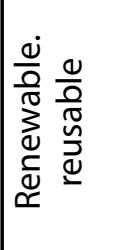 & 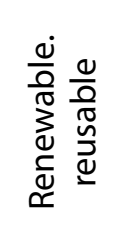 & 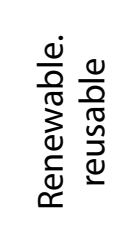 \\
\hline $\begin{array}{l}\text { Use of } \\
\text { Chlorofluoro- } \\
\text { carbons (CFC) }\end{array}$ & - & - & - & + & + & - & - & - & - \\
\hline $\begin{array}{l}\text { Effects of } \\
\text { environment } \\
\text { and human } \\
\text { health }\end{array}$ & 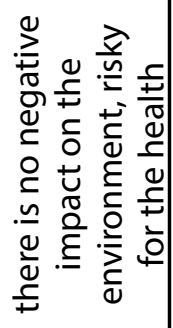 & 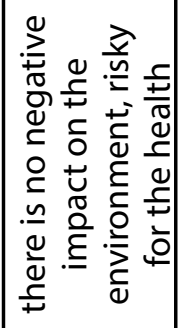 & 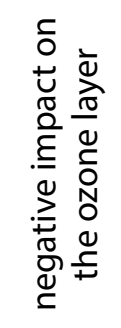 & 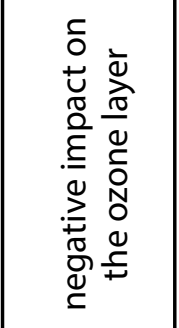 & 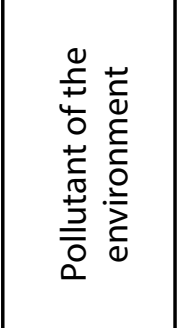 & - & - & - & - \\
\hline $\begin{array}{l}\text { Global } \\
\text { Warming } \\
\text { potential- } \\
\text { GWP (g CO } 2 \text { - } \\
\text { equ/kg) }\end{array}$ & 1740 & 1700 & 14500 & 21500 & 3500 & 500 & 5 & 600 & 230 \\
\hline
\end{tabular}

A good insulating material in terms of sustainability is material that fulfill criteria given in table 3. 
Table 4: Values of sustainability criteria for good insulation material, $[1,2,26]$

\begin{tabular}{|c|c|c|c|c|c|c|}
\hline \multicolumn{7}{|c|}{ Sustainability criteria } \\
\hline 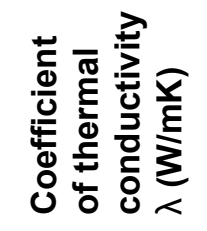 & 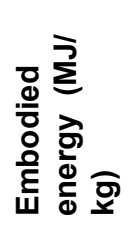 & 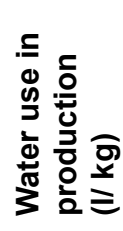 & 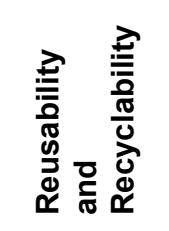 & $\begin{array}{l}0 \\
\text { U. } \\
4 \\
0 \\
0 \\
0 \\
0\end{array}$ & 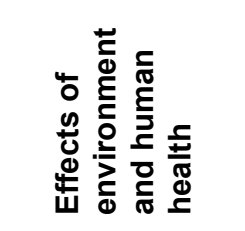 & 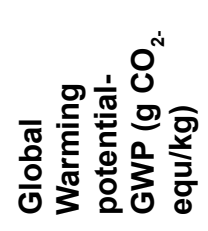 \\
\hline $0.02 \div 0.035$ & $\leq 50$ & none & favorable & no & $\begin{array}{l}\text { Without toxic } \\
\text { gases or toxins }\end{array}$ & $\leq 500$ \\
\hline
\end{tabular}

\section{CONCLUSION}

The introduction of the concept of "sustainability" encouraged many studies intended at developing alternative insulating materials for buildings using textile materials. Some of them are already present in the market, while others are still at an early stage of production or study. Evaluation of insulation materials according to the sustainability criteria shows that no single material fulfills all sustainability criteria, but some materials are more sustainable than others. Because of the negative effects they have on human health along with the degree to which they affect global warming and them being either not at all recyclable or not being reusable, conventional insulation materials score rather poorly in terms of sustainability in the context of the life cycle assessment. Insulation materials that are organic, innovative and that contain recycled components are more sustainable than conventional insulation materials. Insulating materials from recycled textiles are considered to be sustainable materials according to the LCA, mostly due to the possibility of recycling, reuse and their low value of embodied energy. Applying textile waste as an insulation material may have environmental, sustainable and economic advantages. However, as a result of insufficient consumer awareness, insulating materials from recycled textiles are not present in the markets as much as they deserve to be.

\section{REFERENCES}

[1] Papadopoulos, A.M. (2005). State of the art in thermal insulation materials and aims for future developments, Energy and Buildings, 37(1), 77-86.

[2] Papadopoulos, A.M. et al. (2005). Composite insulating materials as a tool for the reduction of cooling loads, International Conference, Passive and Low
Energy Cooling, May, 2005, Santorini, Greece, 803808.

[3] Materijali za toplinska izolacija (http://elektricniaparati.weebly.com/uploads/5/4/ 8/7/5487717/materijali_za_toplinska_izolacija. pdf/ available: 14/03/2019)

[4] Министерство за животна средина и просторно планирање на Р. Македонија Национален План за Управување со Отпад 2009-2015, (http://www.moepp.gov.mk/wp-content/uploads/2014/12/Nac.plan-za-upravuvanje-so-otpad-2009-2015.pdf,/available: 14/03/2018)

[5] Jelle, B. P. et al. (2010). The path to the high performance thermal building insulation materials and solutions of tomorrow, Journal of Building Physics, 34(2), 99-123.

[6] Zach, J. et al. (2012). Performance evaluation and research of alternative thermal insulations based on sheep wool, Energy and Buildings, 49, 246-253.

[7] Inno-thermB ${ }^{\circledast}$. Natural Thermal and Acoustic Insulation/, (http://www.inno-therm.com/, available: 27.11.2018).

[8] Lerelais.org. (http://www.lerelais.org. /available: 14/03/2014).

[9] Blog. emap.com. EMAP, (http://blog.emap.com/ footprint/2011/08/11/scotlands-waste-textiles-turned-into-insulation/available: 15.04.2014).

[10] Paiva, A. et al. (2011). Textile subwaste as a thermal insulation building material, International Conference on Petroleum and Sustainable Development, Sinagpore, 2011, 26, 78-82.

[11] Valverde, I.C. et al. (2013) Development of new insulation panels based on textiles recycled Fab- 
rics, Waste and Biomass Valorization, 4(1), 139146.

[12] Narang, P. P. (1995). Material parameter selection in polyester fibre insulation for sound transmission and absorption, Applied Acoustics, 45(4), 335-358.

[13] Asdrubali, F. (2007) Green and sustainable materials for noise control in buildings, 19-th International Congress on Acoustics, Madrid, 2007.

[14] Intini, F. \& Kühtz, S. (2011). Recycling in buildings: An LCA case study of a thermal insulation panel made of polyester fiber, recycled from post-consumer PET bottles, The International Journal of Life Cycle Assessment, 6(4), 306-315.

[15] Trajković, D., Jordeva S., Tomovska, E. \& Zafirova K. (2017). Polyester apparel cutting waste as insulation material, The Journal of The Textile Institute, 108(7), 1238-1245, DOI: 10.1080/00405000.2016.1237335

[16] Jordeva S., Tomovska E., Trajković D., Zafirova K. (2014).Textile waste as a thermal insulation material. Tekstil, 63 (5-6), 174-178.

[17] Jordeva S., Tomovska E., Trajković D., Zafirova K. (2014). Application of apparel cutting waste as insulation material, 6-th International Textile Conference, 46-49. Tirana, Albania

[18] Jordeva S, Tomovska E, Trajković D, Zafirova K., (2016). Some characteristics of a new insulation structure from recycled apparel cutting waste, XXIV Congress of chemists and technologists of Macedonia, Ohrid.

[19] Jordeva S., Tomovska E., Trajković D., Popeski-Dimovski., P., Zafirova, K.. (2015). Sound insulation properties of structure designed from apparel cutting waste, 15th AUTEX World Textile Conference 2015, 10-12 June 2015, Bucharest, Romania.

[20]http://citeseerx.ist.psu.edu/viewdoc/download?do $i=10.1 .1 .671 .2618 \&$ rep $=$ rep $1 \&$ type $=p d f /$ available: 27.11.2018).

[21] Anastaselos, D., Giama E., Papadopoulos, A.M., (2009). An assessment tool for the energy, economic and environmental evaluation of thermal insulation solutions, Energy and Buildings, 41, 1165-1171.

[22] Srebrenkoska, V., et al. (2013). Treatment of textile wastes, Sustainable Technologies and Chemical Industry, Ed. Jašić M., et. al., Tuzla: Tehnološki Fakultet, 129-135.

[23] En.wikipedia.org (http://en.wikipedia.org/ wiki/Global-warming_potential\#Calculating_the_global-warming_potential, /available: 14.02.2014).

[24] https://www.egenius.at/fileadmin/user upload/ daemmstoffe eigenschaften/en/Insulation $\% 20$ Materials Properties.pd/ available: 18.02.2018.

[25] Life Cycle Assessments of Natural Fibre Insulation Materials, Study funded by DEFRA, Final Report 2008, (http://eiha.org/media/attach/372/lca_fibre.pdf, /available: 05.07.2017).

[26] Idil, A. and Tuna, M. (2013). Evaluation of insulation materials in the context of sustainability criteria, Asian Transactions on Basic and Applied Sciences, 3(2), 38-46.

Rad primljen: 16.05.2019.

Rad prihvaćen: 15.06.2019. 